\title{
PERKAWINAN ANTAR PEMELUK AGAMA DI INDONESIA
}

\author{
Oleh: Afrian Raus* \\ Program Studi Hukum Ekonomi Syariah STAIN Batusangkar \\ J1. Jenderal Sudirman No. 137, Lima Kaum Batusangkar \\ e-mail: afrian.raus@yahoo.com
}

\begin{abstract}
The Acts Number 1 Year 1974 does not directly discuss about the marriage of future couple coming from different religious beliefs. Consequently, such marriage cannot be done in Indonesia following Chapter 2 verse 1 and Chapter 8 part $f$ and supported by the opinions of other relegions (i.e Catholic, Protestant, Buddha and Hindu). However, such marriage can be accommodated as long as it is done in other country where it is allowed by its rules and officially registered to Civil Registration office in Indonesia.
\end{abstract}

Kata kunci: perkawinan, beda, agama

\section{PENDAHULUAN}

N egara Indonesia sebagai Negakeberadaan beberapa agama sudah sewajarnya memiliki sistem hukum yang bisa menaungi seluruh agama yang ada. Suatu aturan yang berlaku di Negara harus memenuhi rasa keadilan bagi semua warga Negara yang menganut agama yang berbeda. Aturan tersebut seharusnya bisa mengatur warga negara dalam satu agama maupun warga negara antar umat agama.

Aturan perkawinan yang berlaku saat ini kelihatannya belum bisa mewujudkan keteraturan bagi semua penganut agama di Indo-nesia. Materi yang diatur dalam sebuah aturan seringkali berbenturan antara satu sama lainnya menyebabkan ketidakteraturan masyarakat dalam mengamalkannya. Persoalan makin bertambah rumit dan perilaku masyarakat makin beragam dengan pendapat para ahli yang berbeda penafsiran dan berbeda aturan yang diyakininya.

Perkawinan antar pemeluk agama yang dilakukan oleh warga Negara Indonesia merupakan bukti kongkrit pertanda lemahnya suatu aturan yang ada. Meskipun di satu sisi materi yang termuat dalam aturan perkawinan sudah jelas namun di sisi lain ada muatan materi yang membuat konsistensi suatu aturan menjadi terganggu.

Perkawinan antar pemeluk agama seringkali diperdebatkan oleh para ahli hukum di Indonesia yang berakibat kepada perilaku masyarakat. Maka tulisan ini akan melihat suatu fenomena yang terjadi dan akan dibahas berdasarkan peraturan yang ada secara komprehensif sehingga bisa menarik suatu kesim-

* Penulis adalah Asisten Ahli dalam Mata Kuliah Hukum Perdata Islam di Indonesia STAIN Batusangkar 
pulan yang membantu masyarakat dalam melakukan suatu tindakan hukum.

\section{PERKAWINAN ANTAR PEME- LUK AGAMA MENURUT UN- DANG-UNDANG}

Undang-undang No. 1 tahun 1974 sebagai Undang-undang perkawinan di Indonesia tidak memuat tentang perkawinan antar pemeluk agama, yang dimuat hanya tentang perkawinan campuran. Yang dimaksud dengan perkawinan campuran menurut Undang-undang No.1 tahun 1974 ialah perkawinan dua orang yang ada di Indonesia tapi tunduk pada hukum yang berlainan karena perbedaan kewarganegaraan dan salah satu pihak berkewarganegaraan Indonesia. (sebagaimana yang diatur dalam Pasal 57)

Perkawinan campuran yang diatur dalam Pasal 57 Undangundang No.1 tahun 1974 adalah perkawinan antara seorang warga Negara Indonesia dengan seorang berkebangsaan asing. Dan perkawinan seperti ini termasuk ke dalam hukum perdata Internasional. (T. Jafizham, 2006: 81)

Sungguhpun demikian ada beberapa interpretasi yang berkembang dengan tidak diaturnya perkawinan antar pemeluk agama ini di dalam Undang-undang No. 1 tahun 1974.

Pertama, tidak diaturnya perkawinan antar pemeluk agama, dengan demikian, tidak ada larangan di dalam Undang-undang tentang perkawinan antar pemeluk agama, sepanjang institusi agama dimana calon mempelai mengizinkan perkawinan tersebut kemudian baru dicatatkan. Interpretasi ini menguat karena pada kenyataannya banyak pihak yang melakukan perkawinan antar pemeluk agama. (Nasul Umam Syafi'i dan Ufi Ulfiah, 2004:187)

Kedua, perkawinan antar pemeluk agama tidak dibolehkan. Interpretasi ini didasarkan pada Pasal 2 ayat 1 yang menyebutkan bahwa perkawinan adalah sah jika dilakukan berdasarkan ajaran agama masing-masing. Jika dilihat dari sejarah munculnya pasal ini, adalah sebagai pasal kompromi, dan tidak salah jika dikatakan ada pagar yang sengaja dibuat untuk menghindari perkawinan antar pemeluk agama dengan berbagai argumentasi tafsir agama. Karena pada umumnya setiap agama (interpretasi agama) menyarankan pemeluknya untuk kawin satu agama. ( Nasul Umam Syafi'i dan Ufi Ulfiah, 2004:187)

Selain itu ahli hukum berdalil tentang kebolehan perkawinan antar agama ini dengan tidak diaturnya secara jelas oleh Undang-undang No. 1 tahun 1974 dengan menggunakan Pasal 66 Undang-undang ini. Pasal 66 tersebut menyebutkan "Untuk perkawinan dan segala sesuatu yang berhubungan dengan perkawinan berdasarkan atas Undang-undang ini, maka dengan berlakunya Undang-undang ini ketentuan-ketentuan yang diatur dalam Kitab Undang-undang Hukum Perdata Burgelijk Wetboek), Ordinansi Perkawinan Indonesia Kristen (Huwelijk Ordanantie Christen Indonesia 1933 No.74, 
Peraturan Perkawinan Campuran (Regeling op gemengde Huwelijken S.1898 No. 158), dan Peraturanperaturan lain yang mengatur tentang perkawinan sejauh telah diatur dalam Undang-undang ini, dinyatakan tidak berlaku"

Pasal 66 tersebut di atas memberi peluang untuk berlakunya peraturan lain sepanjang tidak di atur dalam Undang-undang No.1 tahun 1974. Peraturan lain yang dimaksud adalah Peraturan Perkawinan Campuran (Gemengde Huwelijken Regeling/GHR). Perkawinan campuran yang dimaksud dalam peraturan ini adalah perkawinan dua orang yang di Indonesia tunduk pada hukum yang berlainan. Seperti seseorang yang tunduk kepada hukum Eropa sementara yang lain tunduk kepada hukum adat dan atau hukum agama.

Peraturan Perkawinan Campuran yang terdapat dalam Stbl 1898 No. 158 memiliki persamaan dan perbedaan dengan Undang-undang No. 1 tahun 1974. Persamaannya adalah sama-sama berada di Indonesia. Sedangkan perbedaannya adalah; Stbl 1898 No. 158 tentang perkawinan campur menitikberatkan pada perbedaan golongan penduduk, lingkungan hukum adat, perbedaan agama dan lain-lain. Sedangkan perkawinan campuran yang terdapat dalam Undangundang No. 1 tahun 1974 mengkhususkan perbedaan kewarganegaraan.

Berhubung perkawinan antar pemeluk agama tidak dibunyikan dalam Undang-undang No. 1 tahun 1974 ini, maka aturan perkawinan antar pemeuluk agama yang berada dalam lingkup Peraturan Perkawinan Campuran dapat diberlakukan.

Dengan demikian perkawinan campur yang di atur dalam Stbl 1898 No.158 sepanjang tidak ada perbedaan kewarganegaraan masih tetap dapat dilangsungkan di Indonesia, karena tidak dibicarakan dalam Undang-undang No.1 tahun 1974. ( T. Jafizham, 2006: 398)

Pasal 1 Peraturan Perkawinan Campuran menyebutkan "yang dinamakan perkawinan campuran ialah perkawinan antara orang-orang yang di Indonesia tunduk pada hukum-hukum yang berlainan". ( Stbl 1898 No. 158) Kalimat "tunduk pada hukum-hukum yang berlainan" di atas termasuk tunduk pada hukum agama, hukum adat dan hukum Negara. (O.S. Eoh, Sh, MS, 2001: 32). Seperti pendapat Prof. Mr. Soedargo Gautama yang dikemukakan oleh O.S. Eoh, Sh, MS.

Prof. Mr. Dr. Sudargo Gautama berpendapat sebagaimana yang dikemukakan oleh Nasrun Umam Syafi'i: Agama tidak boleh menjadi penghalang dari segi hukum untuk orang melangsungkan suatu perkawinan. Jika seorang wanita dan pria suka sama suka hendak melangsungkan perkawinan tetapi agama mereka berbeda, maka tidak wajar memakai agama ini sebagai penghalang untuk perkawinan mereka. Seperti diketahui menurut kenyataan agama manapun sedapatnya menghendaki bahwa pemeluk agama-agama itu kawin dengan orang yang mempunyai agama yang sama. Tapi dari segi hukum, hal ini tidak berlaku secara mutlak. Orang berbeda agama pun dapat dibenarkan kawin dengan yang lain 
tanpa perlu terlebih dahulu mengubah agama mereka ini. Dilihat dari segi ajaran agama, maka pendirian yang demikian tidak dapat dibenarkan. (Nasrun Usmam Syafi'i dan Ufi Ulfiah, 2004: 182)

Meskipun secara eksplisit Peraturan Perkawinan Campuran ini menjamin berlangsungnya perkawinan orang yang berbeda agama, namun bagi perempuan bukan hal yang mudah, disebabkan:

Pertama, perkawinan campuran pada prinsipnya menjadikan perempuan sebagai jembatan perkawinan campuran. Perempuanlah yang harus menundukan diri dan mengubah status hukumnya mengikuti hukum laki-laki. Pasal 2 misalnya, menyebutkan bahwa perempuan yang melakukan perkawinan campuran berubah statusnya menjadi mengikuti status hukum suaminya. Sebagaimana disebutkan pada peraturan tersebut, bahwa perkawinan campuran ialah perkawinan antara orang-orang (laki-laki maupun perempuan) yang tunduk pada hukum yang berlainan, maka perkawinan campuran dapat dilakukan dengan penundukkan hukum. Bisa juga disebut pemilihan hukum dimana orang tersebut akan tunduk pada hukum yang dipilihnya (pihak perempuan terhadap hukum lakilaki yang menjadi suaminya).

Kedua, Undang-undang mensyaratkan secara mutlak adanya surat keterangan bebas dari rintangan untuk melakukan perkawinan campuran sebagai tertera dalam beberapa pasalnya. Persyaratan tersebut, dapat dilihat pada Pasal 7 dan 8 Peraturan Perkawian
Campuran: perempuan yang akan melakukan perkawinan campuran dengan seorang laki-laki, dibolehkan apabila telah melalui dan tidak bertentangan dengan syarat-syarat yang ditentukan oleh hukum yang berlaku bagi perempuan tersebut.

Berbagai persyaratan di atas, bisa menjadi hambatan, lebih khusus lagi hambatan tersebut akan semakin tampak bagi perempuan dari golongan agama yang jelas-jelas melarang perkawinan dengan lakilaki dari agama lain. (Asmin, 1986: 73)

Dengan demikian, meskipun Peraturan Perkawinan Campuran menjamin terjadinya perkawinan antar pemeluk agama, namun dalam prakteknya selalu menemukan kendala. Hal ini karena cara pandang dan keyakinan terhadap nilai tertentu tentang perkawinan antar pemeluk agama tidak dianjurkan lebih kuat. Namun peraturan ini dapat dikatakan memberi peluang untuk terjadinya perkawinan antar pemeluk agama.

Pasal 7 ayat 2 Peraturan Perkawinan Campuran yang berbunyi "perbedaan agama, suku maupun keturunan tidak dapat menjadi penghalang untuk berlakunya perkawinan".

Kalimat "tunduk pada hukum yang berlainan" yang terdapat dalam Peraturan Perkawinan Campuran lebih umum sifatnya jika dibandingkan dengan Pasal 57 yang terdapat dalam Undang-undang No. 1 tahun 1974. karena dalam Pasal 57 tersebut dengan jelas dinyatakan "tunduk pada hukum yang berlainan karena berbeda kewarga- 
negaraan dan salah satu pihak berkewarganegaraan Indonesia. Kekhususan yang terdapat dalam Undang-undang No. 1 tahun 1974 tidak bisa mencegah terjadinya perkawinan antar pemeluk agama. Karena perbedaan agama tidak tercakup dalam Pasal 57 Undangundang No. 1 tahun 1974 tersebut.

Orang Islam yang melakukan perkawinan dengan orang yang berbeda agama, maka perkawinan tersebut tidak bisa dicatatkan di Kantor Urusan Agama tetapi dicatat di Kantor Catatan Sipil. Karena perkawinan orang yang beragama di luar Islam hanya dicatat di Kantor Catatan Sipil. Hal ini sesuai dengan Keputusan Presiden No. 12 tahun 1983 menyebutkan bahwa Kantor Catatan Sipil hanya berwenang mencatat perkawinan orang-orang yang non Islam saja. Berdasarkan Keputusan Presiden tersebut, jelas sekali menutup peluang terjadinya perkawinan umat Islam dengan non Islam yang berada di Indonesia.

Undang-undang No. 1 tahun 1974 memberikan pemahaman, bahwa perkawinan antar pemeluk agama tidak dibolehkan karena pasal 2 ayat 1 menyebutkan "perkawinan adalah sah apabila dilakukan menurut hukum masing-masing agamanya dan kepercayaannya itu" pasal ini menegaskan dalam pandangan hukum produk Negara sah atau tidaknya perkawinan seseorang didasarkan pada ketentuan agama masing-masing. Jadi, perkawinan harus sah terlebih dahulu menurut hukum agama baru kemudian bisa dicatat oleh Kantor Catatan Sipil sebagai suatu perkawinan yang sah secara yuridis.
Pada dasarnya perkawinan antar pemeluk agama ini ditolak oleh semua agama. Pendapat beberapa agama yang memberikan indikasi, bahwa perkawinan antar pemeluk agama ini ditolak oleh semua agama:

Agama Katholik menolak perkawinan antar pemeluk agama ini seperti yang dikemukakan oleh O.S. Eoh, Sh, MS, salah satu halangan yang dapat mengakibatkan perkawinan tidak sah yaitu perbedaan agama. Bagi Gereja Katholik menganggap bahwa perkawinan antara seorang yang beragama Katholik dengan orang yang bukan Katholik dan tidak dilakukan menurut hukum agama Katholik dianggap tidak sah. Di samping itu perkawinan antara seorang yang beragama Katholik dengan orang yang bukan Katholik bukanlah perkawinan yang ideal. (O.S. Eoh, Sh, MS, 2001: 119)

Agama Protestan pada dasarnya juga menolak perkawinan antar pemeluk agama ini. Pada prinsipnya agama Protestan menghendaki agar penganutnya kawin dengan orang yang seagama, karena tujuan utama perkawinan untuk mencapai kebahagiaan, sehingga kebahagiaan sulit tercapai kalau suami isteri tidak seiman.( O.S. Eoh, Sh, MS, 2001: 123)

Menyadari adanya kehidupan bersama dengan umat lain, maka gereja tidak melarang penganutnya melangsungkan perkawinan dengan orang yang bukan beragama Protestan. Perkawinan orang yang berbeda agama ini dapat dilangsungkan di gereja menurut hukum Gereja Protestan apabila pihak yang tidak beragama Protestan menyatakan tidak keberatan secara tertulis. Gereja Kristen Indonesia telah meng- 
atur perkawinan berbeda agama yang bersifat rinci dengan kesediaan pihak yang tidak Kristen untuk kawin di gereja dan anaknya dididik secara Kristen. (Ichtiyanto, 2003: 132133)

Agama Hindu juga menolak perkawinan antar pemeluk agama ini. Menurut Gde Pudjda sebagaimana yang dikutip oleh O.S. Eoh, Sh, MS "suatu perkawinan batal karena tidak memenuhi syarat, bila perkawinan itu dilakukan menurut hukum Hindu tetapi tidak memenuhi syarat untuk pengesahannya, misalnya mereka tidak menganut agama yang sama pada saat upacara perkawinan itu dilakukan". Pedande/Pendeta menolak untuk mengesahkan perkawinan orang yang beragama Hindu dengan orang yang beragama lain. (Ichtiyanto, 2003: 125)

Agama Budha menganggap perkawinan antar pemeluk agama dimana salah seorang calon mempelai tidak beragama Budha, menurut keputusan Sangha Agung Indonesia diperbolehkan asal pengesahan perkawinannya dilakukan menurut tata-cara agama budha. Dalam hal ini calon mempelai yang tidak beragama Budha tidak diharuskan untuk masuk agama Budha terlebih dahulu. Akan tetapi dalam upacara ritual perkawinan kedua mempelai diwajibkan mengucapkan "atas nama Sang Budha, Dharma dan Sangka" yang merupakan DewaDewa umat Budha. (Ichtiyanto, 2003: 125)

Agama Budha pada dasarnya juga menolak perkawinan antar pemeluk agama, karena dalam suatu upacara perkawinan kedua calon mempelai diwajibkan mengikuti tata-cara perkawinan yang ada dalam agamanya. Ini menandakan bahwa sah atau tidaknya suatu perkawinan ditentukan oleh agama Budha.

Pendapat beberapa agama di atas memberikan pemahaman, bahwa perkawinan antar pemeluk agama dilarang.

Sudah seharusnya pasal 2 ayat 1 Undang-undang No. 1 tahun 1974 dipahami, bahwa yang menentukan sah tidaknya suatu perkawinan adalah hukum agama. Kata "kepercayaannya itu" dalam Undang-undang No. 1 tahun 1974 tersebut pemahamannya adalah kepercayaan yang ada dalam agama itu dan bukan pemahaman lain seperti aliran kepercayaan.

Undang-undang diciptakan pada dasarnya bertujuan untuk ketertiban umat dan bukan sebaliknya. Akan tetapi dengan menggunakan bahasa yang tidak jelas memberi peluang kepada warga Negara untuk memahami lain yang berlawanan dengan tujuan Undangundang tersebut.

Pasal 2 ayat 1 yang menyatakan "perkawinan adalah sah, apabila dilakukan menurut hukum masingmasing agamanya dan kepercayaannya itu" bisa dipahami "apabila perkawinan dilakukan dimana kedua calon mempelai yang berbeda agama melangsungkan perkawinan menurut hukum satu agama, maka perkawinan itu dibolehkan.

Negara Indonesia hanya mengakui orang yang beragama, dengan kata lain kalau seseorang 
yang tidak beragama ingin melangsungkan suatu perkawinan di Indonesia, maka keinginan itu tidak bisa dilakukan. Orang yang berlainan agama tidak mungkin bisa melakukan perkawinan, karena perkawinan yang dilangsungkan menurut ajaran satu agama tidak mungkin disahkan oleh dua agama. Ditambah lagi semua agama yang ada di Indonesia pada dasarnya menolak perkawinan orang yang berbeda agama.

Uraian di atas memberikan pemahaman, bahwa perkawinan antar pemeluk agama tidak dibolehkan di Indonesia, karena tidak satupun agama yang menghendakinya. Bahkan penulis lebih cenderung mengatakan bahwa perkawinan antar pemeluk agama di Indonesia merupakan pelanggaran terhadap Undang-undang perkawinan. Di samping telah menyalahi Pasal 2 ayat 1 yang telah disebutkan di atas juga tidak sesuai dengan Pasal 8 huruf (f) yang menyatakan perkawinan dilarang antara dua orang yang "mempunyai hubungan yang oleh agamanya atau peraturan lain yang berlaku, dilarang kawin".

Pasal 8 Undang-undang No. 1 tahun 1974 mengatur tentang larangan perkawinan, maka bunyi Pasal 8 huruf (f) mengandung makna bahwa, semua aturan atau ketentuan agama yang melarang terjadinya perkawinan bisa berlaku. Dengan kata lain siapa saja yang tidak mengindahkan ketentuan larangan agama, maka perilaku itu termasuk melanggar aturan agama. Pelanggaran tersebut sama halnya dengan melanggar Undang-undang.

Menyikapi hal tersebut di atas, maka di Indonesia perlu adanya penyempurnaan Undang-undang No. 1 tahun 1974 tentang Perkawinan menyangkut perkawinan antar pemeluk agama, baik secara langsung pada pasal-pasalnya, maupun melalui upaya membentuk Undang-undang baru yang khusus mengenai perkawinan umat Islam.

Kompilasi Hukum Islam (khususnya Pasal 40 huruf c) merupakan pasal yang layak dan perlu dikukuhkan dalam Undang-undang. Undang-undang yang mengatur tentang perkawinan umat Islam merupakan kebutuhan mendesak, karena peradilan agama belum memiliki hukum terapan (materil) sebagai materi Undang-undang, maka ketentuan mengenai larangan umat Islam kawin dengan non muslim hendaknya dilengkapi dengan sanksi tegas baik sanksi yang dapat dijadikan sebagai dibatalkannya perkawinan maupun sanksi hukuman badan yang selama ini kosong.

Di samping itu, perlu adanya upaya pengkajian secara mendalam mengenai berbagai materi hukum Islam, khususnya yang berkaitan dengan masalah-masalah sosial kemasyarakatan. Hasil kajian itu tersebut hendaknya disosialisasikan secara memadai melalui berbagai media yang ada. Dari upaya ini kiranya dapat menepis persepsi yang keliru terhadap hukum Islam yang seolah-olah hanya membahas mengenai peribadatan saja, atau hukum Islam itu kejam, ketinggalan zaman, bertentangan dengan prinsip HAM dan kesan buruk lainnya. Yang akhirnya materi hukum Islam muncul kepermukaan dalam per- 
aturan perundang-undangan yang berlaku di Negara Indonesia.

\section{PROSEDUR PENCATATAN PER- KAWINAN ANTAR PEMELUK AGAMA DI INDONESIA}

Pencatatan Perkawinan ini telah diatur dalam Undang-undang No. 1 tahun 1974. Pasal 2 ayat 2 menyebutkan bahwa "Tiap-tiap perkawinan dicatat menurut peraturan perundang-undangan yang berlaku". Di samping itu juga dimuat dalam Undang-undang No. 23 tahun 2006 tentang Administrasi Kependudukan.

Materi yang terdapat dalam Undang-undang Perkawinan cenderung melarang perkawinan antar pemeluk agama seperti yang telah dijelaskan di atas. Namun perkawinan tersebut banyak terjadi, hal ini disebabkan karena prosedur pencatatan perkawinan itu di akomodir oleh Undang-undang.

Pasal 56 Undang-undang No. 1/1974 tentang perkawinan di luar Indonesia menyebutkan "Perkawinan yang dilangsungkan di luar Indonesia antara dua orang warga negara Indonesia atau seorang warga negara Indonesia dengan warga negara Asing adalah sah bilamana dilakukan menurut hukum yang berlaku di negara di mana perkawinan itu dilangsungkan dan bagi warganegara Indonesia tidak melanggar ketentuan-ketentuan Undang-undang ini.

Perkawinan antar pemeluk agama yang dilaksanakan di Indonesia tidak memiliki kekuatan hukum. Artinya perkawinan ter- sebut tidak memiliki legalisasi hukum karena perkawinannya di bawah tangan.

Perkawinan antar pemeluk agama yang dilakukan oleh sesama warga negara Indonesia dan atau salah satu pihak berkewarganegaraan Indonesia jika ingin dicatatkan di tempat pencatatan perkawinan harus dilakukan di luar negara Indonesia. Pasal 56 Undang-undang Perkawinan di atas menjadi payung hukum bagi pelaku perkawinan tersebut untuk mendapat legalitas formal.

Perkawinan antar pemeluk agama yang dilakukan di luar negara Indonesia tersebut baru bisa diakui apabila negara tempat melangsungkan perkawinan itu membolehkan dan atau melegalkan perkawinan tersebut. Artinya perkawinan tersebut mendapatkan legalitas sebuah negara ditandai dengan surat/ akte resmi perkawinan yang dikeluarkan oleh pejabat yang berwenang di negara tersebut.

Bukti resmi perkawinan yang diperoleh dari negara tempat melangsungkan perkawinan tersebut menjadi dasar untuk melakukan pencatatan perkawinan di Indonesia. Namun ketika bukti tersebut dikeluarkan oleh pejabat yang tidak berwenang tentunya tidak bisa dijadikan dasar untuk pencatatan perkawinan di Indonesia. Hal ini berarti negara tempat melangsungkan perkawinan tersebut tidak membolehkan perkawinan itu ataupun perkawinan yang dilangsungkan tidak mengikuti peraturan sebuah negara.

Waktu yang diberikan oleh Undang-undang untuk melakukan 
pencatatan perkawinan antar pemeluk agama yang dilakukan di luar wilayah negara Indonesia tersebut dibatasi selama 1 tahun semenjak dilangsungkannya perkawinan itu. Hal ini ditegaskan oleh Undangundang perkawinan Pasal 56 ayat 2 "dalam waktu 1 (satu) tahun setelah suami istri itu kembali di wilayah Indonesia, surat bukti perkawinan mereka harus didaftarkan di Kantor Pencatat perkawinan tempat tinggal mereka.

Materi hukum yang termuat dalam Undang-undang perkawinan agaknya berseberangan dengan prosedur pencatatan perkawinan. Hal ini terlihat dari materi yang menyangkut perkawinan antar pemeluk agama cenderung dilarang sesuai dengan pasal yang telah di sebutkan di atas. Tentunya Undangundang sudah seharusnya tidak memberi peluang bagi perkawinan antar pemeluk agama untuk dicatatkan. Akan tetapi undang undang mengakomodir bagi pelaku perkawinan tersebut untuk dicatatkan. Hal ini menandakan bahwa Undang-undang yang mengatur tentang materi dan atau ketentuan perkawinan tidak sejalan tentang prosedur pencatatannya.

Muatan Undang-undang yang tidak sejalan antara pasal dengan pasal yang lain akan memberikan kontribusi terhadap ketidakefektifan jalannya sebuah Undang-undang. Hal ini ditandai dengan pro dan kontranya masyarakat dalam menanggapi kebolehan suatu praktek perkawinan antar pemeluk agama. Akibatnya terlihat dari banyaknya terjadi praktek perkawinan tersebut oleh warga negara.
Undang-undang No. 23 Tahun 2006 Tentang Administrasi Kependudukan, Pasal 35 menyebutkan Pencatatan perkawinan sebagaimana dimaksud dalam Pasal 34 berlaku pula bagi (a) perkawinan yang ditetapkan oleh Pengadilan dan (b) perkawinan Warga Negara Asing yang dilakukan di Indonesia atas permintaan Warga Negara Asing yang bersangkutan.

Penjelasan Pasal 35 ini menyebutkan bahwa perkawinan yang ditetapkan oleh pengadilan adalah perkawinan yang dilakukan antar umat berbeda agama. Hal ini menandakan bahwa perkawinan antar umat beragama bisa juga dicatatkan di tempat pencatatan perkawinan apabila perkawinan tersebut sudah ditetapkan oleh pengadilan.

Persoalannya kemanakah perkawinan antar pemeluk agama itu dicatatkan, apakah ke Kantor Urusan Agama atau ke Kantor Catatan Sipil. Karena Pasal 34 dan penjelasan Undang-undang No. 23 tahun 2006 hanya menyebutkan perkawinan yang sah yang dilakukan oleh penduduk yang beragama Islam dilaporkan kepada Kantor Urusan Agama atau Kantor Catatan Sipil. Hal ini menandakan bahwa pencatatan perkawinan yang dilakukan oleh orang-orang yang beragama Islam ke Kantor Urusan Agama dan perkawinan orang-orang yang tidak beragama Islam ke Kantor Catatan Sipil.

Pasal 2 Peraturan Pemerintah tahun 1975 menyebutkan (1) Pencatatan perkawinan dari mereka yang melangsungkan perkawinannya menurut agama Islam, dilakukan oleh Pegawai Pencatat sebagaimana dimaksud dalam Undang-undang Nomor 32 
Tahun 1954 tentang Pencatatan Nikah, Talak dan Rujuk. (2) Pencatatan perkawinan dari mereka yang melangsungkan perkawinannya menurut agamanya dan kepercayaannya itu selain agama Islam, dilakukan oleh Pegawai Pencatat perkawinan pada Kantor Catatan Sipil sebagaimana dimaksud dalam berbagai perundang-undangan mengenai pencatatan perkawinan.

Peraturan Pemerintah tersebut di atas memberikan pemahaman kepada kita bahwa Perkawinan yang dilakukan oleh orang Islam dengan Non Islam hanya bisa dicatatkan di Kantor Catatan Sipil.

\section{PENUTUP}

\section{Kesimpulan}

Perkawinan antar pemeluk agama tidak bisa dilangsungkan di wilayah hukum Negara Indonesia karena peraturan perundang-undangan yang berlaku cenderung tidak membolehkan seperti yang termuat dalam Undang-Undang No. 1 tahun 1974 tentang perkawinan. Sekalipun bermacam dalih yang dikemukakan oleh para ahli untuk terlaksananya sebuah perkawinan, hal itu hanya celah yang dicari untuk

\section{DAFTAR PUSTAKA}

Asmin, 1986. Status Perkawinan antar Agama, ditinjau dari Undangundang No.1 tahun 1974, Jakarta: PT Dian Rakyat,

Eoh, O.S. Sh, MS, 2001. Perkawinan Antar Agama Dalam Teori dan melegalisasi perkawinan antar pemeluk agama.

Terjadinya perkawinan antar pemeluk agama di Indonesia akibat dari prosedur pencatatan perkawinannya diakomodir oleh aturan yang berlaku. Undang-undang perkawinan mengatur prosedur pencatatan perkawinan yang dilangsungkan di luar wilayah hukum Indonesia. Maka perkawinan antar pemeluk agama tidak bisa dilaksanakan di Indonesia namun perkawinan yang dilangsungkan di luar negeri bisa dicatatkan di institusi pencataan perkawinan, hal ini yang dijadikan landasan berpijak bagi pelaku perkawinan antar pemeluk agama.

\section{Saran}

Penganut agama yang baik adalah orang yang selalu menjalankan aturan agamanya secara baik dan dan konsisten tanpa mencari celah untuk membenarkan semua tindakannya. Hal ini menjadi syarat dalam mewujudkan suatu keteraturan dalam hidup bernegara, maka sudah seharusnya warga Negara tidak melakukan perkawinan antar pemeluk agama sebagaimana kehendak dari masing-masing agamanya.

Praktek, Jakarta: PT Raja Grafindo Persada, cet ke-2

Ichtiyanto, 2003. Perkawinan Campuran dalam Negara Republik Indonesia, Jakarta: Badan Litbang Agama dan Diklat 
Keagamaan Departemen Agama Republik Indonesia

Jafizham, T, 2006, Persintuhan Hukum Di Indonesia Dangan Hukum Perkawinan Islam, Jakarta: PT Mestika.

Peraturan Pemerintah Nomor 9 tahun 1975 tentang Pelaksanaan Undang-undang Nomor 1 tahun 1974 tentang Pekawinan

Stbl 1898 No. 158 tentang Peraturan Perkawinan Campuran

Syafi'i, Nasul Umam, dan Ufi Ulfiah, 2004. Ada Apa dengan Nikah Beda
Agama, Tangerang: Qultum Media.

Republik Indonesia. 1974. Undangundang Nomor 1 tahun 1974 tentang Perkawinan, Lembaran Negara RI Tahun 1974 No. 1. Jakarta: Sekretariat Negara

Republik Indonesia. 2006. Undangundang Nomor 23 tahun 2006 tentang Administrasi Kependudukan, Lembaran Negara RI Tahun 2006 No. 124. Jakarta: Sekretariat Negara 